\title{
PENGEMBANGAN TABUH TARI WALI SANGGAR SENI PARI GADING DESA PUPUAN SAWAH, KECAMATAN SELEMADEG, KABUPATEN TABANAN
}

Oleh:

\author{
I Ketut Gede Rudita \\ gederudita@unhi.ac.id \\ Dosen Fakultas Pendidikan, UNHI Denpasar \\ I Putu Gede Padma Sumardiana \\ padmasumardiana@unhi.ac.id \\ Dosen Fakultas Pendidikan, UNHI Denpasar \\ Ida Ayu Putu Sari \\ iasari@unhi.ac.id \\ Dosen Fakultas Pendidikan, UNHI Denpasar
}

\begin{abstract}
ABSTRAK
Secara umum bahwa yang dimaksud tabuh hubungannya dengan gamelan adalah membunyikan atau menyuarakan gamelan. Mungkin dengan cara memukul, meniup, menggesek dan lain-lain. Tetabuhan atau tabuh-tabuhan diartikan alunan suara gamelan yang sedang dalam pergelaran, sebagai pendukung upacara atau iringan suatu tari-tarian. Khusus didalam pengertian karawitan Bali, bahwa yang dimaksud tabuh adalah hasil kemampuan seniman mencapai keseimbangan permainan dalam mewujudkan suatu repertoire (reportoar) hingga sesuai dengan jiwa, rasa dan tujuan komposisi. Menabuh bukan berarti asal memukul gamelan mengikuti suatu melodi, tetapi memukul gamelan dengan segala aturan atau tata cara yang telah ditentukan supaya suara gamelan dapat terdengar indah. Keindahan yang ditimbulkan dari suara gamelan, bukan hanya tergantung dari satu faktor saja misalnya, karena baiknya komposisi lagu yang dimainkan, tetapi keindahan itu terjadi akibat keseimbangan antara faktorfaktor komposisi lagu, suara gamelan itu sendiri termasuk larasnya, tata cara atau aturan menyuarakan gamelan, keterampilan serta kemampuan seniman menjiwai permainan lagulagunya itu. Pelaksanaan tradisi keagamaan di Desa Pupuan Sawah selalu diiringi oleh tabuh atau gamelan untuk menunjukan suatu estetika atau keindahan serta mengandung makna penuh kesakralan.
\end{abstract}

Kata Kunci: Pengembangan, Tabuh tari wali, Sanggar seni

\section{ABSTRACT}

In general, what is meant by percussion has to do with sounding the gamelan. Maybe by hitting, blowing, swiping and others. Tet Port or percussion is interpreted by the sound of gamelan music in a performance, as a supporter of a ceremony or accompaniment of a dance. Specifically in Balinese musical meaning, what is meant by percussion is the result of the artist's ability to achieve a balance of the game in realizing a repertoire (reportoar) to match the soul, taste and purpose of the composition. Beating does not mean the origin of hitting the gamelan following a 
melody, but hitting the gamelan with all the rules or procedures that have been determined so that the sound of the gamelan can be heard beautifully. The beauty arising from the sound of the gamelan, not only depends on one factor, for example, because the composition of the song is played well, but the beauty occurs due to a balance between the song composition factors, the sound of the gamelan itself including the barrel, the procedures or rules for voicing the gamelan, skills and the artist's ability to animate the song's play. The implementation of religious traditions in the Pupuan Sawah Village is always accompanied by percussion or gamelan to show an aesthetic or beauty and contain the full meaning of sacredness.

Keywords: Development, Tabuh, Guardian dance, Art studio

\section{PENDAHULUAN}

Secara umum bahwa yang dimaksud tabuh hubungannya dengan gamelan adalah membunyikan atau menyuarakan gamelan. Mungkin dengan cara memukul, meniup, menggesek dan lain-lain. Tetabuhan atau tabuh-tabuhan diartikan alunan suara gamelan yang sedang dalam pergelaran, sebagai pendukung upacara atau iringan suatu tari-tarian. Khusus didalam pengertian karawitan Bali, bahwa yang dimaksud tabuh adalah hasil kemampuan seniman mencapai keseimbangan permainan dalam mewujudkan suatu repertoire (reportoar) hingga sesuai dengan jiwa, rasa dan tujuan komposisi. Keindahan yang ditimbulkan dari suara gamelan, bukan hanya tergantung dari satu faktor saja misalnya, karena baiknya komposisi lagu yang dimainkan, tetapi keindahan itu terjadi akibat keseimbangan antara faktor-faktor komposisi lagu, suara gamelan itu sendiri termasuk larasnya, tata cara atau aturan menyuarakan gamelan, keterampilan serta kemampuan seniman menjiwai permainan lagu-lagunya itu (Rembang,1934/1985: 8).

Pendidikan nonformal di Bali khususnya biasa disebut Sanggar Belajar atau Sanggar Seni, Sanggar Seni adalah unit atau tempat di mana anak diajarkan suatu keahlian yang kelak dapat digunakan oleh anak itu sendiri, dan anak akan mengetahui Seni (Prawira, 2019). Sanggar seni di Bali biasanya Sanggar Seni Tari, Sanggar Seni Tabuh, Sanggar Seni Lukis dan banyak lagi Sanggar Seni lainnya. Namun yang dominan diminati oleh anak-anak adalah Sanggar Seni Tari dan Sanggar Seni Tabuh, Sanggar Seni Tari adalah suatu Sanggar yang berfokus untuk mengajarkan tarian-tarian bali, dan Sanggar Seni Tabuh sudah jelas mengajarkan anak-anak menabuh.

Sanggar Seni Pari Gading Desa Pupuan Sawah Kecamatan Selemadeg, Kabupaten Tabanan memiliki semangat untuk berpartisipasi aktif dalam menjaga kelestarian kesenian Bali. Apa lagi dalam kehidupan sehari-hari mereka terlibat 
langsung dalam proses kehidupan beragama yang tidak lepas dari kesenian itu sendiri (Suadnyana, 2019). Selama ini, karena berbagai macam hambatan, pengembangan tabuh tari wali yang dilaksanakan di Sanggar Seni Pari Gading Desa Pupuan Sawah masih terkesan otodidak, sehingga akansangat menarik untuk mangkaji bentuk pengembangan tabuh tari wali ditengah animo masyarakat yang meningkat dalam upaya mengenal tabuh tari wali yang memang sesuai dengan kaidah-kaidah dalam seni karawitan.

\section{PEMbahasan}

\subsection{Bentuk Pengembangan Tabuh Tari} Wali Di Sanggar Seni Pari Gading Desa Pupuan Sawah, Kecamatan Selemadeg, Kabupaten Tabanan

\subsubsection{Tahap Pertama}

Sanggar Pari Gading sangatlah menjaga Tradisi dan Seni Budaya dilihat dari, Sanggar Pari Gading memiliki ciri tersendiri yaitu ketika proses pembinaan menabuh yang mengikuti sanggar tersebut menggunakan pakaian adat ringan (adat madya), Dimulai dengan teknik gagebug. Gagebug atau teknik menabuh gambelan merupakan suatu hal yang pokok dalam gambelan Bali. Gagebug atau teknik permainan gambelan bukan hanya sekedar keterampilan memukul dan menutup belahan gambelan, tetapi mempunyai konotasi yang lebih dalam dari pada itu. Gagebug mempunyai kaitan yang erat dengan orkestrasi dan menurut prekempa bahwa hampir setiap instrument mempunyai Gagebug tersendiri dan mengandung aspek "Physical Behavior" dari instrument tersebut. Sifat fisik dari instrumentinstrumen yang terdapat dalam gambelan tersebut member keindahan masing-masing pada penikmatnya. Selain itu penabuh juga diajarkan nada dasar pada gambelan dengan mengenal notasi : Ding, Dong, Deng, Dung, Dang selain kelima nada tersebut ada yang dinamakan nada pelog seperti Ding, Dong, Ndung, Dung, Nding. Ketuju nada tersebut merupakan sumber bunyi dalam gambelan Bali dan menurut banyak orang disebut Genta Pinara Pitu (Bunyi Berjarak Tujuh). ( Dr. I Made Bandem "lontar prekempa" )

Pada saat sudah memahami hal tersebut, selanjutnya diajarkan beberapa tabuh dasar seperti tabuh gilak, pola tabuh gilak yaitu dalam satu klotomik gong terdiri dari delapan ketukan, yaitu ketukan keempat dan kedelapan terdapat gong, ketukan kekelima dan ketujuh terdapat kempur. Akan tetapi seiring perkembangan jaman, proses inovasi selalu terjadi, maka dari itu pada era ini gilak tidak mutlak lagi harus 
delapan ketukan dalamsatu klomatik, melainkan ada yang tujuh, sembilan, sepuluh dan lain sebagainya, akan tetapi akar atau pola gilak tetap berangkat dari asumsi delapan dari satu klotimik, sedangkan menurut (Pande Made Sukerta dalam buku Ensiklopedi Karawitan Bali) menyebutkan Gilak adalah nama dari salah satu bentuk gending yang dapat disajikan di beberapa perangkat gambelan yang berlaras selendro atau pun pelog, seperti pada perangkat-perangkat gambelan Gong Gede, Gong Kebyar, Semar Pegulingan, Angklung. Gending-gending gilak biasanya disajikan dalam irama cepat atau tanggung, tanggung dari gaya tabuhan daerah setempat yang biasanya terdiri dari satu sampai empat gongan yang disajikan secara berulangulang. Dalam proses belajar tabuh gilak di sanalah penabuh diajarkan ornament atau ornamitasi lagu dalam bentuk ketukan, disebut noltol, onot, dan oncang-oncangan. Para Pendidik atau Pelatih di sanggar Pari gading menggunakan sistem rotasi pada saat latihan, cara ini digunakan untuk mengetahui seberapa keahlian penabuh dan agar pelatih mampu menempatkan penabuh pada tempat atau instrument gambelan, melihat dari bakat anak-anak atau penabuh.

\subsubsection{Tahap Kedua}

Tahap kedua yang dilakukan oleh pendidik kepada penabuh ketika penabuh sudah memahami proses pembelajaran pada tahap pertama tentang cara menabuh atau megambel serta mengenai tabuh dasar gilak selanjutnya diberikan materi ajar atau pembelajaran mengenai Tabuh Petegak. Tabuh petegak iyalah jenis gending yang sajiannya tidak dikaitkan dengan jenis kesenian lain atau gending mandiri yang tidak berfungsi sebagai iringan. Jenis gending petegak terdapat pada seluruh perangkat gambelan yang biasanya disajikan sebelum pertunjukan jenis kesenian lainnya, misalnya pertunjukan tari, dramatari, topeng dan sebagainya. Beberapa contoh gendinggending tabuh petegak dalam perangkat gambelan gong kebya antara lain Purwa Pascima, Kosalia Arini, Sekarini, dan Jaya Semara. Tabuh petegak terdiri dari beberapa bagaian seperti Pengawit, Pengawak, Pengecet dan Pekaad.

Pengawit dapat diartikan sebagai asal, awal, pertama, timbul dan muncul. Pertama kali istilah kawitan digunakan pada gending-gending gambang dan kidung, dalam gending-gending terdapat bagian awal dari suatu gending yang disebut dengan kawitan kaping pisan atau kawitan kapertama. Bagian gending yang disajikan paling awal lainnya diantaranya adalah 
pengerangrang dan kebyar, kawitan atau pengawit biasanya memiliki ciri antara lain mempunyai kalimat lagu yang pendek dan disajikan oleh satu tungguhan atau satu jenis tungguhan.

Pengawak adalah nama dari bagian awal gending sesudah bagian gendinggending kawitan. Pengawak diantaranya terdapat pada gending-gending Gong Gede, Gong Kebyar, Semar Pegulingan Saih Pitu, Semar Pegulingan Saih Lima (gendinggending pelegongan), dan Pegambuhan. Pada gending-gending pada perangkat gambelan lainnya sebenarnya ada pada bagian gendingnya seperti pengawak, tetapi tidak pernah disebutkan dengan bagian gending pengawak seperti misalnya pada perangkat gambelan Angklung, Joged Bumbung, Gambang dan sebagainya. Bagaian gending pengawak biasanya memiliki ciri-ciri sebagai berikut terdiri dari satu gongan atau lebih dan dapat disajikan berulang-ulang, strukturnya jelas dan dapat menentukan bentuk gendingnya.

Pengecet nama dari salah satu gending yang biasanya terletak pada bagian akhir. Ada dua macam bentuk bagian pengecet yaitu : (1) Pengecet pada gending lelambatan antara lain pengecet yang didalamnya terdiri dari beberapa bentuk gending, seperti halnya pada bagian gending pengecet yang terdapat pada bentuk-bentuk gending tabuh pat, nem, kutus. (2) Pengecet pada gending-gending iringan tari. Bagian gending pengecet ini terdiri dari satu gongan atau lebih, yang disajikan secara berulangulang. Jenis gending ini biasanya untuk mengiringi tari dalam adegan atau bentuk pengipuk atau aras-arasan.

Pekaad adalah nama dari salah satu gending-gending gong kebyar jenis petegak, bagian gending ini disajikan akhir sajian gending oleh semua tungguhan, cirri-ciri bagian pekaad antara lain bentuk dan strukturnya yang jelas, dapat disajikan berulang-ulang, serta adanya penonjolan garap tungguhan tertentu, seperti gangsa, riyong, dan ceng-ceng. Dengan kata lain bagian gending pekaad seolah-olah berfungsi sebagai penutup keseluruhan gending yang disajikan.

\subsubsection{Tahap Ketiga}

Ketika penabuh telah mengikuti pembelajaran tahap pertama mengenai tabuh gilak dan tahap kedua mengenai tabuh petegak dan penabuh cukup menguasai materi yang diberikan penabuh tersebut, untuk tahap selanjutnya penabuh diajarkan atau diberikan materi tabuh iringan tari seperti tabuh tari pendet, tari puspanjali, tari gopala dan tari baris. 
Tari Pendet ini diciptakan oleh dua orang maestro tari Bali yaitu I Wayan Rindi dan Ni Ketut Reneng pada tahun 1950. Pada awalnya tari Pendet merupakan taripemujaan yang banyak diperagakan di pura, tempat ibadah umat Hindu di Bali, Indonesia. Tarian ini melambangkan penyambutan atas turunnya dewata ke alam dunia. Menurut tradisi Bali, para penari Pendet haruslah gadis yang belum menikah, karena dalam tarian tersebut mereka membawa saji-sajian suci untuk para dewa. Namun lambat-laun, seiring perkembangan zaman, para seniman Bali mengubah tari Pendet menjadi "ucapan selamat datang", meski tetap mengandung anasir yang sakral-religius. Pencipta atau koreografer bentuk modern pada tari ini adalah I Wayan Rindi pada tahun 1967.

Pendet merupakan pernyataan dari sebuah persembahan dalam bentuk tarian upacara. Tidak seperti halnya tarian-tarian pertunjukkan yang memerlukan pelatihan intensif, Pendet dapat ditarikan oleh semua orang, pemangku pria dan wanita, dewasa maupun gadis. Tarian ini diajarkan sekedar dengan mengikuti gerakan dan jarang dilakukan di banjar-banjar. Para gadis muda mengikuti gerakan dari para wanita yang lebih senior yang mengerti tanggung jawab mereka dalam memberikan contoh yang baik.

Tari putri ini memiliki pola gerak yang lebih dinamis dari pada Tari Rejang yang dibawakan secara berkelompok atau berpasangan. Biasanya ditampilkan setelah Tari Rejang di halaman pura dan biasanya menghadap ke arah suci (pelinggih) dengan mengenakan pakaian upacara dan masingmasing penari membawa sangku, kendi, cawan, dan perlengkapan sesajen lainnya. Adapun orkes gamelan yang mengiringi tari Pendet ini ialah gamelan gong, atau gamelan palegongan, atau gamelan semar pagulingan. Tari Pendet merupakan tarian masal yang bisa dibawakan oleh empat penari, enam penari, delapan atau lebih.

Tari Puspanjali yang berarti (puspa $=$ bunga, anjali $=$ menghormat) merupakan sebuah tarian penyambutan yang ditarikan oleh sekelompok penari putri (biasanya antara 5-7 orang). Menampilkan gerak-gerak lembut lemah gemulai yang dipadukan dengan gerak-gerak ritmis yang dinamis, tarian ini banyak mengambil inspirasi dari tarian-tarian upacara Rejang, dan menggambarkan sejumlah wanita yang dengan penuh rasa hormat menyongsong kedatangan para tamu yang datang ke pulau mereka. Tari ini diciptakan oleh N.L.N. 
Swasthi Wijaya Bandem (penata tari) dan I Nyoman Windha (penata tabuh pengiring) pada tahun 1989.

Tari Gopala merupakan tarian yang bertemakan kerakyatan yang ditarikan sekelompok anak-anak atau remaja Putra, dimana tarian ini digarap oleh I Nyoman Suarsa sebagai penata tari dan I Ketut Gede Asnawa,MA sebagai penata tabuh, diambil dari penggalan cerita pragmentari : "STRI ASADHU" Karya Ibu Ketut Arini,S.St. Tarian ini diciptakan pada tahun 1983. Gopala adalah sebuah istilah dalam bahasa Kawi yang berarti penggembala sapi. Tarian ini merupakan tari kelompok, dan biasanya ditarikan oleh 4 sampai 8 orang penari putra. Dalam tarian Gopala ini menceritakan aktivitas yang dilakukan oleh para pengembala di ladang pertanian atau sawah. Semua aktivitas tadi dituangkan kedalam bentuk garapan tari misalnya: gerakan binatang sapi, memotong rumput, menghalau burung, membajak sawah, menuai padi dan gerak lain-lainnya yang berhubungan dengan aktivitas petani. Gerak tersebut di atas di olah menjadi pola garap yang berbau baru dengan nuansa estetika kekinian. Gerakan tari ini menjadi hidup apabila dilakukan dengan sungguh-sungguh dan semangat.
Tari Baris merupakan salah satu tarian sakral yang digunakan oleh umat Hindu di Bali sebagai pelengkap di suatu upacara keagamaan agama Hindu di Bali. Sifat sakral dalam tari Baris ialah, bahwa tari ini merupakan sebuah tarian untuk membuktikan kedewasaan seseorang dalam segi jasmani. Kedewasaan seseorang pria dibuktikan dengan mempertunjukkan kemahiran dalam olah keprajuritan yang biasanya disertai dengan kemahiran dalam memainkan senjata perang. Maka dari itu, tari Baris selain merupakan tarian sakral juga merupakan tari kepahlawanan. Adapun ciri khas dari tari Baris ialah, pertama tari ini lebih menonjolkan ketegapan dan kemantapan dalam langkah langkah kaki serta kemahiran memainkan senjata perang. Kedua, pakaiannya juga mempunyai corak yang khas, yaitu penutup kepalanya bebebtuk kerucut, dan penutup badannya terdiri dari baju panjang serta hiasan kain - kain kecil panjang yaitu awir dan lelamakan.

Tari Baris terbagi menjadi 2 bagian, salah satunya adalah tari Baris Tunggal. Tari baris tunggal merupakan tarian sakral yang digunakan pada saat Upacara Pitra Yadnya yaitu Karya mamukur, dimana disini tari baris tunggal berfungsi sebagai sarana penghatur punia atau persembahan bagi para 
leluhur yang dihantarkan dengan mantramantra suci Sulinggih dan alunan gamelan pengiring tari baris tunggal itu sendiri. Tari baris tunggal merupakan tarian lepas yang dibawakan oleh seorang laki-laki, dimana menggambarkan seorang prajurit gagah perkasa yang memiliki kematangan jiwa dan kepercayaan dimana itu diperlihatkan dengan gerakan tari yang dinamis dan lugas. Berbeda dengan tari Baris Tunggal sakral, tari Baris Tunggal Profan juga biasanya ditampilkan sebagai tari lepas dalam beragam pagelaran seni pertunjukan balihbalihan.

Dari data yang penulis peroleh jumlah penabuh yang mengikuti sanggar Pari gading pada proses belajar menabuh sekitar 195 orang, mengingat jumlah penabuh yang begitu banyak pengurus sanggar berserta dengan pelatih mengambil inisiatif untuk membagi waktu latihan pada hari Rabu, Kamis, Jumat, dan Sabtu pada pukul 14.30 wita, 15.30 wita, 16.30 wita dan 17.30 wita. Pembagian waktu yang begitu banyak bertujuan agar para Pembina mampu mengajarkan dengan maksimal dan mengoftimalkan proses pembelajaran

kepada peserta

\subsection{Proses pembelajaran tabuh tari wali di Sanggar Seni Pari Gading Desa \\ Pupuan Sawah, Kecamatan \\ Selemadeg, Kabupaten Tabanan}

\section{Pengenalan Alat}

Pengenalan alat penting untuk dilakukan, agar siswa dapat mengetahui nama-nama alat yang terdapat dalam gamelan Gong Gede. Pengenalan nama alat ini dilakukan secara satu persatu agar siswa dapat mengetahui nama alat, fungsi alat. Nama- nama alat dan fungsi alat disebutkan antara lain:

1) Instrumen kendang adalah instrumen yang tergolong pada golongan madya, yang berfungsi sebagai pemimpin dari sebuah barungan gambelan. Instrumen kendang biasanya dmainkan secara berpasangan dan individu. Jika dimainkan secara berpasangan dinamakan kendang lanang wadon. Jenis kendang dalam karawitan bali dibagi menjadi Sembilan jenis kendang yaitu Kendang mebarung, kendang tambur, kendang bedug, kendang cedugan, kendang gupekan, kendang bebarongan, kendang 
krumpungan, kendang batel, kendang angklung.

2) Instrumen Riong adalah suatu instrumen yang berbentuk memanjang. Instrumen ini memiliki jumlah moncol/pencon sebanyak 12 buah dengan susunan nada dari nada : 571345713457 dibaca ndeng, ndung, ndang, nding, ndong, ndeng, ndung, ndang, nding, ndong, ndeng, dan ndung. berfungsi sebagai memangku lagu, Reyong dimainkan oleh empat orang penabuh dengan mempergunakan masing-masing dua buah panggul pada tangan kanan dan kiri. Teknik permainan yang diterapkan adalah tehnikubit-ubitan yang dalam barungan gamelan sepadan dengan cecandetan, kotekan, tetorekan yang mengacu pada teknik permainan polos dan sangsih.

3) Instrumen Terompong adalah barungan gong kebyar memiliki sepuluh buah moncol/pencon yang merupakan nada ndang rendah sampai nada ndung tinggi. Instrumen ini dimainkan oleh seorang penabuh dengan dua tangan memakai panggul yang disebut panggul trompong. Dalam sebuah barungan, instrument ini berfungsi untuk pembawa lagu, juga membuka/pengawit sebuah gending yang dalam barungan membawa melodi dengan tekniknya tersendiri. Sistem ini adalah gambaran keindahan permainan trompong yang dalam sub tekniknya seperti: Ngembat, Ngempyung, Nyilih asih, nguluin, nerumpuk, ngantu, niltil, ngunda dan ngoret.

4) Instrumen gangsa jongkok adalah instrumen pelawahnya rendah yang mempunyai berupa lubang dibawah bilahannya yang langsung dibuat pada pelawahnya yang berfungsi sebagai pembawa lagu pokok suatu gending.

5) Instrumen jublag adalah suatu instrumen yang memiliki jumlah bilah lima buah, dengan susunan nada 34571 dibaca nding, ndong, ndeng, ndung, ndang. Besar kecilnya nada diambil dari instrument ugal/giying. Fungsinya dalam sebuah barungan adalah sebagai pemangku lagu, memperkuat/mempertegas melodi pada ruasruas gending. Teknik pukulan yang diterapkan adalah: neliti, magending, nyele/nyelah. 
6) Instrumen Penyacah adalah instrumen ini mempunyai jumlah bilah sebanyak tujuh buah dengan susunan nada: 1345713 dibaca ndang, nding, ndong, ndeng, ndung, ndang. berfungsi sebagai pemangku lagu/mempertegas jalannya melodi (pukulannya lebih rapat dari jublag).Secara fisik ukurannya lebih kecil dari instrument Jublag. Teknik permainannya sangat melodis pada setiap matra lagu.

7) Instrumen jegog adalah instrumen bilah yang paling besar ukurannya. Instrument ini memiliki bilah sebanyak lima buah dengan susunan nada 34571 dibaca nding, ndong, ndeng, ndung ndang. Instrumen ini berfungsi sebagai pemangku lagu dan memberikan aksentuasi kuat pada ruas-ruas gending (pukulannya lebih jarang dari jublag).

8) Instrumen gong adalah instrumen berpencon yang ukurannya paling besar. Terbuat dari kerawang dan memiliki ukuran diameter 65 - 90 $\mathrm{cm}$. Dilihat dari fungsinya, instrumen ini berfungsi sebagai finalis lagu (menghakhiri lagu).

9) Instrumen kempur adalah instrumen berpencon yang besarnya memiliki diameter 50-60 cm. Dengan digantung pada sebuah sangsangan, instrumen ini berfungsi sebagai pemangku irama (ritme) dan sebagai pematok ruas-ruas gending serta sebagai pemberi aksen-aksen sebelum jatuhnya gong. Pola pukulannya dapat memberikan identitas ukuran tabuh yang dibawakannya.

10) Instrumen ceng-ceng kopyak adalah instrumen dipegang oleh dua tangan dan dimainkan dengan dibenturkan sesuai tekniknya. Adapun beberapa jenis pukulannya adalah: pukulan malpal, ngecek, ngelumbar dan lainlain. Sedangkan fungsinya dalam barungan adalah untuk memperkaya ritme/angsel-angsel tanpa memakai teknik jalinan.

11) Instrumen kempli adalah instrumen yang ketuknya sama seperti kajar, instrumen kempli dimainkan dengan menggunakan sebuah panggul yang bentuknya serupa dengan panggul kempur yang ukurannya lebih pendek fungsinya sebagai pemangku irama.

a. Dianggap indikator mengenali alat ketika siswa mampu membedakan alat 
yang ada dalam gamelan gong gede ini dan masingmasing fungsi instrumen tersebut.

b.

\section{Pengenalan Teknik Pukulan}

Dalam gamelan Bali teknik atau gegbug itu sangat penting, bukan hanya memukul atau menutup gamelan saja tetapi mempunyai kenotasi yang lebih daripada itu. Pada saat memainkan gamelan disana pemain gamelan merasakan keindahan dalam memukul gamelan, orang yang menikmati dan mendegarkannya juga merasakan keindahan memainkan gamelan tersebut. Dalam pembelajaran praktek Gong Gede ini Siswa diajarkan teknik atau gegebug dan gimana cara memainkannya gambelan Gong Gede. Dalam instrumen gangsa jongkok, kendang, riong, terompong, penyacah, jublag, jegog, gong, kempur, kempli dan ceng-ceng kopyak guru menjelaskan bagaimana cara memukul gamelan yang baik dan benar. Jenis pukulan yang ada dalam gending gajah nongklang ini antara lain:

a) Instrumen Kendang mempunyai jenis pukulan seperti batu-batu, gegilak dan pola tabuh telu. b) Instrumen Terompong mempunyai jenis pukulan seperti ngembat.

c) Instrumen Riong mempunyai jenis pukulan seperti norot dan cecandetan.

d) Instrumen Gangsa Jongkok mempunyai jenis pukulan seperti kekenyongan

e) Instrumen Jegog mempunyai jenis pukulan seperti pukulan ke 4 atau ke 8 dari instrumen jublag

f) Instrumen Penyacah mempunyai jenis pukulan seperti neliti/ memainkan nada pokok suatu gending.

g) Instrumen Jublag mempunyai jenis pukulan seperti neliti/ memainkan nada pokok suatu gending.

h) Instrumen Gong mempunyai jenis pukulan seperti pengatur matra/ struktur pola tabuh telu

i) Instrumen Kempur dan Kempli mempunyai jenis pukulan seperti menyesuaikan dengan pola tabuhnya.

j) Instrumen Ceng-Ceng Kopyak mempunyai jenis pukulan seperti cek 1 sampai cek 8 .

Dianggap indikator mengenali teknik pukulan ketika siswa mampu mempraktikkan jenis pukulan pada masing-masing instrumen tersebut. 
Pengawit dapat diartikan sebagai awal, asal, pertama dan muncul pertama

\section{Pengenalan Nada}

Pada pengenalan nada ini guru mengajarkan siswa mempelajari nada dasar dan mengetahui nada apa saja yang ada pada nada-nada dalam gamelan. Pada gamelan gong gede ini memakai laras pelog dan nada dasarnya ding, dong, deng, dung, dang. Jenis instrumen antara lain:

a) Instrumen Terompong dimulai dari nada Dong.

b) Instrumen Riong dimulai dari nada Dong.

c) Instrumen Gangsa Jongkok dimulai dari nada Dang.

d) Instrumen Jegog dimulai dari nada Dang.

e) Instrumen Penyacah dimulai dari nada Dang.

f) Instrumen Jublag dimulai dari nada Dang.

Dianggap indikator mengenali nada ketika siswa mampu membedakan bunyi nada dan siswa mampu mengetahui penempatan nada dimulai dari nada pada masing-masing instrumen tersebut.

\section{Pengenalan Pengawit}


terdapat pada gending-gending Gong Gede, Gong Kebyar, Semara Pagulingan dan Pegambuhan. Bagian gending pengawak biasanya memiliki ciri-ciri sebagai berikut terdiri dari satu gongan atau lebih dan dapat disajikan berulangulang, strukturnya jelas dan dapat menentukan bentuk gendingnya. Pada pembelajaran Gong Gede ini guru mengajarkan siswanya untuk mengenal pengawak dan teknik pukulan pada masing-masing instrumen seperti terompong. Dianggap indikator mengenali pengawak ketika siswa mampu membedakan ciri-ciri bagian pengawak dan instrumen yang memberi tanda untuk mencari pergantian gending, siswa mampu mengetahui struktur gending pengawak dimulai dari jenis pukulan pada masing-masing instrumen tersebut.

\subsection{Kendala-Kendala yang dihadapi dalam pengembangan tabuh tari wali di Sanggar Seni Pari Gading Desa Pupuan Sawah, Kecamatan \\ Selemadeg, Kabupaten Tabanan}

Pada proses pembelajaran tidak luput dari yang namanya kendala baik itu kendala yang disengaja maupun tidak disengaja yang jelas yang tidak diinginkan oleh pihak sanggar Pari gading selaku pendidik dan para penabuh itu sendiri. Seperti yang terjadi di sanggar Pari gading diantaranya :

\subsubsection{Mental Dan Karakter}

Pada dasarnya mental dan karakter dari penabuh sangat mempengaruhi proses belajar, baik itu proses belajar di sekolah maupun dimasyarakat, pendidikan formal maupun non-formal, begitu pula terjadi pada proses pembelajaran menabuh di Sanggar Pari gading karena penabuh memiliki karekter yang berbeda-beda.

Menurut Bapak I Nyoman Sadia S.Sn mengatakan bahwa kendala yang biasanya dihadapi anak-anak yang memiliki mental atau karakter yang berbeda-beda itu menjadi kendala dalam keaktifan anak-anak didalam memainkan gambelan itu sendiri.

Dari kendala yang dihadapi penabuh yang memiliki mental dan karakter yang berbeda-beda itu Pembina atau Pelatih berinisiatif untuk mendidik dan mengajarkan secara bertahap dan lebih intensif kepada penabuh yang karakter dan mentalnya kurang penabuh tidak menjadi malu saat belajar menabuh.

\subsubsection{Minat dan Bakat}

Bakat adalah kemampuan bawaan yang merupakan potensi yang masih perlu 
dikembangkan atau dilatih untuk mencapai suatu kecakapan, pengetahuan dan keterampilan khusus. Sehubungan dengan cara berfungsinya, ada dua jenis bakat, yaitu (1) Kemampuan pada bidang khusus. Misalnya bakat musik, melukis, dan lainlain. (2) Bakat khusus yang dibutuhkan sebagai perantara untuk merealisir kemampuan khusus, misalnya bakat melihat ruang (dimensi) dibutuhkan untuk merealisasi kemampuan di bidang teknik arsitek (Trisdyani, 2019). Bakat bukanlah merupakan sifat tunggal, melainkan merupakam sekelompok sifat yang secara bertimgkat membentuk bakat. Bakat baru muncul bila ada kesempatan untuk berkembang atau dikembangkan. Sehingga mungkin saja seseorang tidak mengetahui dan mengembangkan bakatnya sehingga tetap merupakan kemampuan yang latent.

Minat adalah aktivitas atau tugastugas yang membangkitkan perasaan ingin tahu, perhatian, dan memberi kesenangan atau kenikmatan. Minat dapat menjadi indikator dari kekuatan seseorang di area tertentu di mana dia akan termotivasi untuk mempelajarinya dan menunjukkan kinerja yang tinggi (Ardiyasa, 2019). Bakat akan sulit berkembang dengan baik apabila tidak diawali dengan adanya minat pada bidang yang akan ditekuni. Minat belajar penabuh sangat menentukan keberhasilannya dalam proses belajar. Ada beberapa faktor yang mempengaruhinya. Faktor-faktor tersebut bersumber pada dirinya dan luar dirinya atau lingkungannya antara lain sebagai berikut : (1) Aspek jasmaniah, mencakup kondisi fisik atau kesehatan jasmani dari individu siswa. Kondisi fisik yang prima sangat mendukung keberhasilan belajar dan dapat mempengaruhi minat belajar. Namun jika terjadi gangguan kesehatan pada fisik terutama indera penglihatan dan pendengaran, otomatis dapat menyebabkan berkurangnya minat belajar pada dirinya. (2) Aspek Psikologis (kejiwaan), faktor psikologis meliputi perhatian, pengamatan, tanggapan, fantasi, ingatan, berfikir, bakat,dan motif. Pada pembahasan berikut tidak semua faktor psikologis yang dibahas, tetapi hanya sebagian saja yang sangat berhubungan dengan minat belajar.

Perhatian merupakan pemusatan energi psikologi yang tertuju kepada suatu objek pelajaran atau kesadaran yang menyertai aktivitas belajar. Tanpa adanya perhatian dalam aktivitas belajar akan berdampak terhadap kurangnya penguasaan materi pelajaran, sehingga hasil yang dicapai dalam belajar kurang memuaskan. Kurangnya perhatian terhadap materi yang dipelajari juga mengakibatkan kurangnya 
minat belajar pada diri penabuh. Ingatan, secara teoritis akan berfugsi untuk mencamkan atau menerima kesan-kesan dari luar, menyimpan kesan, dan memproduksi kesan. Oleh karena itu ingatan merupakan kecakapan untuk menerima, menyimpan, dan memproduksi kesan-kesan di dalam belajar. Penabuh yang mempunyai daya ingat yang kurang sangat berpengaruh terhadap minatnya untuk belajar.

Adapun faktor dari luar penabuh, meliputi, (1) Keluarga, meliputi hubungan antar keluarga, suasana lingkungan rumah, dan keadaan ekonomi keluarga (3) Lingkungan masyarakat, meliputi hubungan dengan teman bergaul, kegiatan dalam masyarakat, dan lingkungan tempat tinggal. Dari uraian tersebut dapat dipahami bahwa faktor-faktor dari diri penabuh dan dar luar penabuh saling berkaitan dalam menumbuhkan minat belajar. Jika faktorfaktor tersebut tidak mendukung mengakibatkan kurang atau hilangnya minat belajar penabuh. Kurang atau hilangnya minat belajar penabuh disebabkan oleh banyak hal yang secara tidak langsung dapat mempengaruhi pencapaian hasil belajar. Menurut JT. Loekmono (1985:97), faktorfaktor yang menyebabkan kurang atau hilangnya minat belajar penabuh adalah sebagai berikut :
1. Kelainan jasmaniah pada mata, telinga, kelenjar-kelenjar, yang sangat mempersukar anak di dalam mengikuti pelajaran atau menjalankan tugas di kelas.

2. Pelajaran kurang merangsang anak. Tingkat kemampuan anak jauh di atas yang diminta di dalam mengikuti pelajaran di kelas, akibatnya anak merasa bosan.

3. Ada masalah atau kesukaran kejiwaan yang menyebabkan dia mundur atau lari dari kenyataan. Dalam hal ini anak akan menunjukkan gejala yang sama dimana-mana, yaitu tidak menunjukkan minat atau memberi perhatian kepada segala sesuatu di luar.

4. Sikapnya yang seakan-akan tidak mempunyai perhatian atau minat ini sebenarnya hanya suatu sikap pura-pura. Keadaan yang sebenarnya ialah bahwa ia ingin memberi kesan demikian, supaya orang dapat menerima kenyataan bahwa ia tidak berkompetisi atau tidak mampu berkompetisi dengan orang lain, yang dipandangnya jauh lebih mampu dari diri sendiri. 
5. Ada konflik pribadi dengan pendidik, atau dengan orang tua. Dengan menunjukkan sikap ini sebenarnya ia hendak menunjukkan sikap melawan mereka, jadi sikap ini merupakan satu jenis senjata untuk melawan.

Ada beberapa faktor-faktor yang dapat menumbuhkan minat belajar, beberapa ahli pendidikan berpendapat bahwa cara yang paling efektif untuk membangkitkan minat pada suatu subyek yang baru adalah dengan menggunakan minat-minat penabuh yang telah ada. Menyarankan agar para pengajar berusaha membentuk minat-minat baru pada penabuh atau penabuh. Hal ini bisa dicapai melalui jalan memberi informasi pada penabuh tentang bahan yang akan dismpaikan dengan menghubungkan bahan pelajaran yang lalu, kemudian diuraikan kegunaannya di masa yang akan datang.

Harry Kitson (dalam The Liang gie 1995:130) mengemukakan bahwa ada dua kaidah tentang minat (the laws of interest), yang berbunyi :

1. Untuk menumbuhkan minat terhadap suatu mata pelajaran, usahakan memperoleh keterangan tentang hal itu

2. Untuk menumbuhkan minat terhadap suatu mata pelajaran, lakukan kegiatan yang menyangkut hal itu.

Minat belajar akan tumbuh apabila kita berusaha mencari berbagai keterangan selengkap mungkin mengenai mata pelajaran itu, umpamanya arti penting atau pesonanya dan segi-segi lainnya yang mungkin menarik. Keterangan itu dapat diperoleh dari buku pegangan. ensiklopedi, guru dan penabuh senior yang tertarik atau berminat pada mata pelajaran itu. Disamping itu perlu dilakukan kegiatan yang berhubungan dengan mata pelajaran itu, misalanya pada mata pelajaran menabuh usahakan mengikuti apa yang harus dilakukan. Dengan langkah-langkah itu minat penabuh terhadap mata pelajaran itu akan tumbuh.

JT. Loekmono (1985:98), mengemukakan bahwa cara-cara untuk menumbuhkan minat belajar pada diri penabuh adalah sebagai berikut :

1. Periksalah kondisi jasmani anak, untuk mengetahui apakah segi ini yang menjadi sebab.

2. Gunakan metode yang bervariasi dan media pembelajaran yang menarik sehingga dapat merangsang anak untuk belajar 
3. Menolong anak memperoleh kondisi kesehatan mental yang lebih baik.

4. Cek pada orang atau pendidik lain, apakah sikap dan tingkah laku penabuh.

5. Mungkin lingkungan rumah anak kurang mementingkan belajar berkesenian. Dalam hal ini orangorang di rumah perlu diyakinkan akan pentingnya belajar berkesenian bagi anak.

6. Cobalah menemukan sesuatu hal yang dapat menarik perhatian anak, atau tergerak minatnya. Apabila minatnya tergerak, maka minat tersebut dapat dialihkan kepada kegiatan-kegiatan lain.

Pendapat lain yang berkaitan dengan upaya menumbuhkan atau meningkatkan minat belajar, dikemukakan oleh Crow and Crow (dalam The Liang Gie 1995:132) yang menyatakan bahwa untuk mendukung tumbuhnya minat belajar yang besar, perlu dibangun oleh motif-motif tertentu dalam batin seseorang penabuh atau penabuh. Ada motif penting yang dapat mendorong penabuh untuk melakukan pembelajaran sebaik-baiknya, yaitu :
1. Suatu dorongan batin untuk memuaskan rasa ingin tahu dalam satu atau lain bidang studi.

2. Hasrat untuk meningkatkan pertumbuhan dan perkembangan pribadi.

3. Hasrat untuk menerima pujian dari orang tua, pendidik, atau teman.

4. Cita-cita untuk sukses di masa depan dalam suatu bidang khusus.

Disamping itu penggunaan media pembelajaran dalam proses belajar mengajar juga dapat menumbuhkan minat belajar penabuh. Hal ini sebagai mana yang dikatakan oleh Hamalik (dalam Arsyad Azhar 2007:15) yang mengemukakan bahwa pemakaian media pembelajaran dalam proses belajar mengajar dapat membangkitkan keinginan dan minat yang baru, membangkitkan motivasi dan rangsangan kegiatan belajar, dan bahkan membawa pengaruh-pengaruh psikologis terhadap penabuh.

Dari beberapa pendapat yang telah dikemukakan dapat dipahami bahwa banyak sekali faktor yang dapat menumbuhkan atau membangkitkan minat belajar bagi penabuh. Tinggal bagaimana upaya yang harus kita lakukan sebagai seorang pendidik dalam memecahkan masalah ini, sehingga penabuh 
terbantu untuk menemukan minatnya dalam mengikuti pembelajaran. Penabuh yang memiliki karakter yang berbeda-beda memerlukan penanganan yang berbeda pula, termasuk dalam hal menumbuhkan minat belajarnya. Dengan adanya upaya dari guru dan pihak lain dalam menumbuhkan minat belajar bagi penabuh, diharapkan dapat mencapai tujuan pembelajaran yang akhirnya tertuju pada keberhasilan belajar penabuh.

Selain itu minat serta bakat sangat mempengaruhi pada proses belajar menabuh seperti contoh ada penabuh yang memiliki minat akan tetapi tidak memimiliki bakat dalam menabuh kemungkinan yang terjadi akan agak lambat untuk menerima dan menguasai gambelan atau gending, sedangkan penabuh yang memiliki bakat jelas dengan mudah atau lebih cepat menguasai gambelan atau gending pada proses belajar menabuh. Akan tetapi jika penabuh memiliki bakat namun karna minatnya yang kurang sudah jelas akan lambat pula menguasai gending atau materi yang diajarkan pada proses belajar menabuh.

Menurut Bapak I Wayan Sudiarsa, S.Sn,M.Sn adalah memotivasi penabuh yang memiliki bakat namun memiliki sedikit minat dan penabuh yang memiliki minat namun kurang memiliki bakat, disinilah peran serta para pelatih untuk memadukan kedua karakter yang berbeda agar menjadi group atau kelompok yang solid dan bagus.

Sanggar Pari gading memiliki beberapa cara untuk menyatukan dua karakter yang berbeda ini agar menjadi group yang solid dan bagus nantinya yaitu penabuh yang memiliki minat namun bakat yang dimiliki penabuh kurang, pelatih di sanggar Pari gading berinisiatif mengabil cara pengajaran yang ektra dari pada penabuh yang lainnya, sedangkan untuk penabuh yang memiliki bakat namun minatnya kurang pendidik memberikan motivasi kepada penabuh agar penabuh yang memiliki bakat menjadi berminat dan penabuh yang hanya memiliki minat menjadi berbakat pula sehingga terbentuklah satu group yang kompak dan bagus nantinya.

\subsubsection{Sarana}

Seperti pembahasan terdahulu dari jumlah penabuh yang mencapai 195 orang, ini juga merupakan salah satu kendala yang dihadapi oleh para pengurus dan pelatih di sanggar Pari gading, karena dari jumlah penabuh yang begitu banyak perlu tempat yang luas, dan sarana yang lainnya seperti 
gambelan (instrument musik ) dan panggul ( alat pemukul instrument ).

Tempat latihan atau proses belajar menabuh di sanggar Pari gading yang sekaligus menjadi tempat tinggal pemilik sanggar dan di sanggar Pari gading hanya terdapat satu Barungan Gong Kebyar yang menjadi instrument atau alat pembelajaran menabuh, disinilah menjadi kendala bagi pemilik sanggar, di karenakan jumlah penabuh yang banyak namun tempat tidak begitu mendukung untuk proses pembelajaran, karena tempatnya tidak terlalu luas. Sedangkan di sanggar Pari gading hanya memiliki satu Barungan Gong Kebyar karena setiap penabuh latihan atau mengikuti proses belajar menabuh pasti menggunakan instrument gambelan yang sama, maka dari itu dipastikan suara atau nada dari gambelan pasti tidak akan menjadi merdu dan sesuai seperti yang diinginkan oleh pelatih.

Melihat kendala dari sarana tersebut Sanggar Pari gading berinisiatif untuk mengatur waktu latihan atau proses belajar menabuh agar pada saat penabuh melakukan proses belajar tidak berebutan instrument music atau gambelan tersebut, sehingga proses pembelajaran akan menjadi lebih maksimal serta intensif dan setiap 6 bualan sekali para pengurus menservise barungan
Gambelan Gong Kebyar yang digunakan oleh penabuh agar tetap menghasilkan suara atau nada yang merdu sesuai yang diinginkan.

\section{PENUTUP}

Keindahan yang ditimbulkan dari suara gamelan, bukan hanya tergantung dari satu faktor saja misalnya, karena baiknya komposisi lagu yang dimainkan, tetapi keindahan itu terjadi akibat keseimbangan antara faktorfaktor komposisi lagu, suara gamelan itu sendiri termasuk larasnya, tata cara atau aturan menyuarakan gamelan, keterampilan serta kemampuan seniman menjiwai permainan lagulagunya itu. Pelaksanaan tradisi keagamaan di Desa Pupuan Sawah selalu diiringi oleh tabuh atau gamelan untuk menunjukan suatu estetika atau keindahan serta mengandung makna penuh kesakralan. Estetika merupakan rasa seni yang diciptakan dan diwujudkan oleh manusia, yang dapat memberikan rasa kesenangan dan kepuasan dengan pencapaian yang penuh keindahan. Seni tabuh dalam pelaksanaan tradisi merupakan satu kesatuan yang saling mendukung dalam rangkaian pelaksanaannya. Serta tabuh dalam pelaksanaan tradisi panca yadnya yang tidak akan lepas dari kehidupan masyarakat dalam 
beryadnya. Tari Wali adalah salah satu aspek terpenting dari kesenian Bali umumnya dan Desa Pupuan Sawah Khususnya yang mempunyai fungsi penting terutama di dalam kehidupan spiritual masyarakatnya.

\section{DAFTAR RUJUKAN}

Ardiyasa, I. Nyoman Suka, and Ida Bagus Putu Eka Suadnyana. "MITIGASI TEOLOGIS BENCANA ALAM DALAM NASKAH LONTAR ROGA SANGHARA

BHUMI." Genta Hredaya 1.1 (2019).

Rembang, I Nyoman. 1934/1985. Hasil Pendukumentasian Notasi Gending-Gending Lelambatan Klasik Pegongan Daerah Bali. Departemen Pendidikan Dan Kebudayaan Direktorat Jendral Kebudayaan Proyek Pengembangan Kesenian Bali.

Suweca, I Wayan. 2009. Estetika Karawitan. Denpasar : Institut Seni Denpasar.

Pula Suarjaya, I Nyoman. 2014. Metode Pembelajaran Seni Gamelan Gong Kebyar Pada Anak Tuna Netra Di SLB A Denpasar. Program Studi Pendidikan Seni Karawitan Keagamaan Hindu. UNHI. Denpasar.

I Nyoman Winyana (2012) "Nilai-Nilai Pendidikan Dalam Seni Karawitan (Studi Kasus
Belajar Gamelan Gong Kebyar di Bale Banjar)". Jurnal Pendidikan Agama dan Seni Jurnal Pendidikan Agama dan Seni volume 2 tahun 2012

Rembang, I Nyoman. 1934/1985. Hasil Pendukumentasian Notasi Gending-Gending Lelambatan Klasik Pegongan Daerah Bali. Departemen Pendidikan Dan Kebudayaan Direktorat Jendral Kebudayaan Proyek Pengembangan Kesenian Bali.

Bandem, I Made. 2013. Gamelan Bali Di Atas Panggung Sejarah. Denpasar : BP Stikom Bali

Djelantik, 2008. Estetika Sebuah Pengantar. Jakarta : MSPI

Dibia, I Wayan. 1977:17. Pengntar Karawitan Bali. Denpasar : Akademi Seni Tari Indonesia

Prawira, I. Made Agus Adi, and Ida Bagus Putu Eka Suadnyana. "FENOMENA NGIRING PADA MASYARAKAT HINDU DI BALI." Genta Hredaya 2.2 (2019).

Suadnyana, Ida Bagus Putu Eka. "AJARAN AGAMA HINDU DALAM GEGURITAN KUNJARAKARNA." Genta Hredaya 3.1 (2019).

Trisdyani, Ni Luh Putu, and Ida Bagus Putu Eka Suadnyana. "ETIKA HINDU DALAM CERITA TANTRI

KAMANDAKA." Jñānasiddh ânta: Jurnal Teologi Hindu 1.1 (2019). 